St. $4-73$

SEP 281998

2. To: (Receiving Organization)
W Root
Hanford Tanks Initiative

5. Proj./Prog./Dept./Div.:

Waste Management
3. From: (Originating Organization) Numatec Hanford Co., Project Definition

6. Design Authority/ Design Agent/Cog. Engr.:

DF Iwatate
8. Originator Remarks:

Transmittal of document for information and release to HTI project files.

11. Receiver Remarks: 11A. Design Baseline Document? [] Yes [X] No
4. Related EDT No.:
N/A
7. Purchase order No.:
$\mathrm{N} / \mathrm{A}$

9. Equip./Component No.:

$N / A$

10. System/Bldg./Facility: $\mathrm{N} / \mathrm{A}$

12. Major Assm. Dug. No.: $N / A$

13. Permit/Permit Application No.: N/A

14. Required Response Date: $\mathrm{N} / \mathrm{A}$

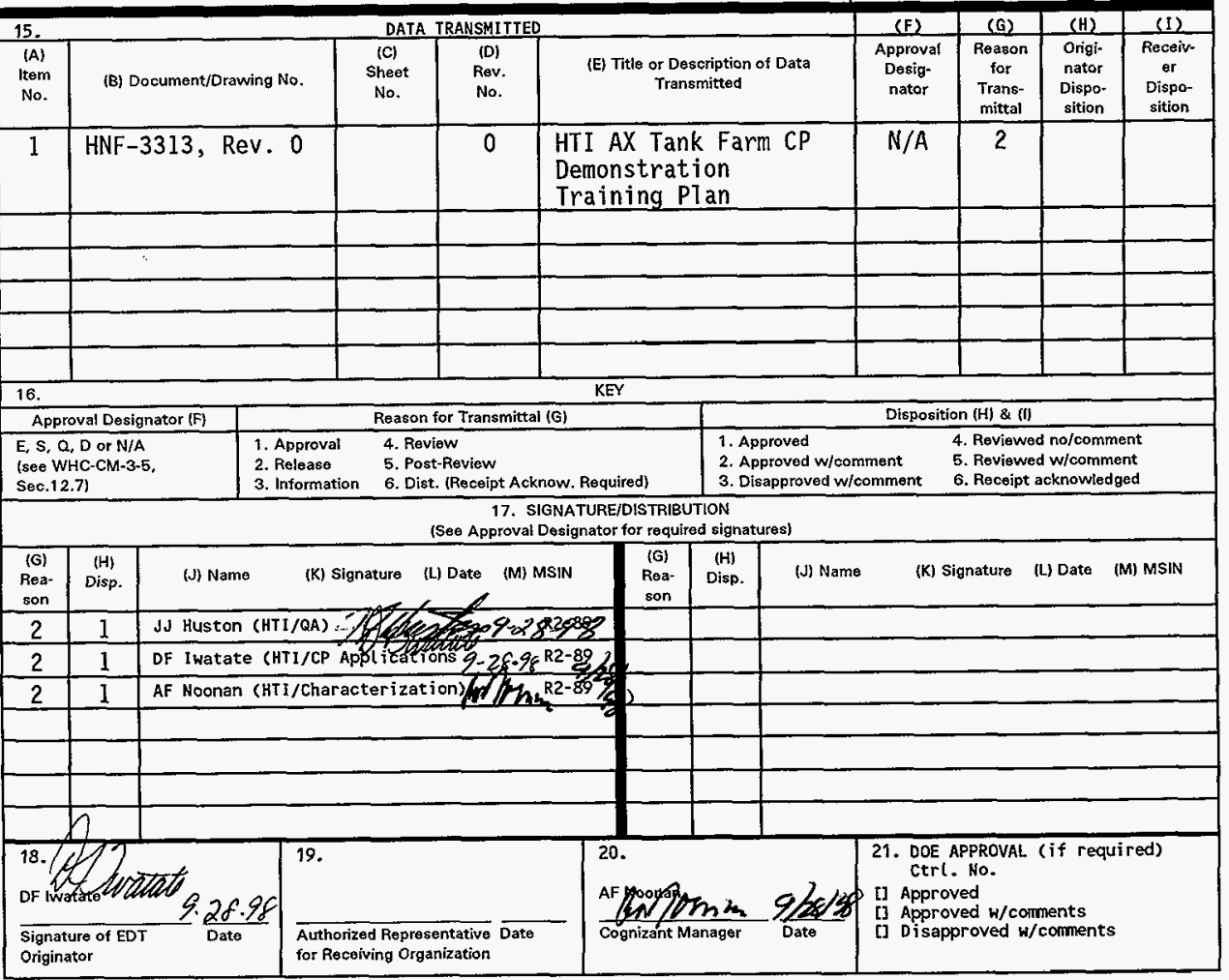




\section{Hanford Tanks Initiative AX Tank Farm Cone Penetrometer Demonstration Training Plan}

D. F. Iwatate

Numatec Hanford Company, Rich1 and, WA 99352-1300

U.S. Department of Energy Contract DE-AC06-96RL13200
EDT/ECN: 609268
UC: 2030
Org Code: 73500
B\&R Code: EW3130010
Charge Code: D25V4 (CP Probe Deptoy Prep) Total Pages: $12 / 1$

Key Words: Single-Shell Tanks, waste, leakage plume, cone penetrometer, gamma, xray fluorescence, vadose zone, soil, soil sampling, AX-104, training

Abstract: The HTI subsurface characterization task will use the Hanford Cone Penetrometer platform (CPP) to deploy soil sensor and sampling probes into the vadose zone/soils around $A X-104$ during $F Y-99$. This training $p l a n$ identifies training requirements in support of the HTI task, describes specific staff training needs, and identifies how the training will be provided and by whom. Documentation of training completion is also described.

TRADEMARK DISCLAIMER. Reference herein to any specific comercial product, process, or service by trade name, trademark, manufacturer, or otherwise, does not necessarily constitute or imply its endorsement, recommendation, or favoring by the United States Government or any agency thereof or its contractors or subcontractors.

Printed in the United States of America. To obtain copies of this document, contact: Document Control services, 9.0. BOK 950, Mailstop H6-08, Richland WA 99352, Phone (509) 372-2420;

Fax $(509) 376-4989$.
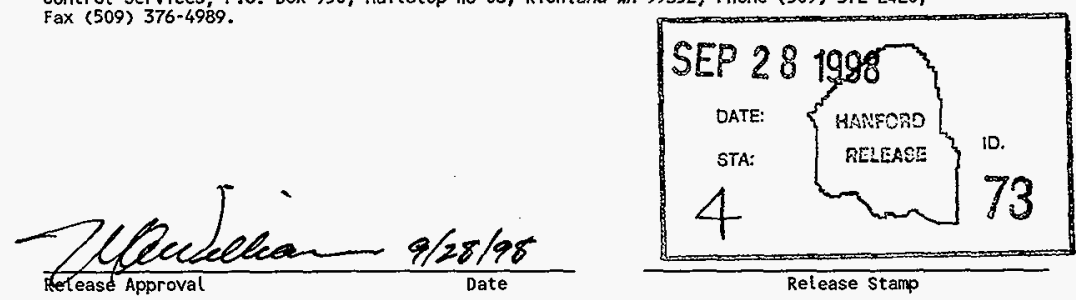

Release stamp

\section{Approved for Public Release}




\section{Hanford Tanks Initiative: AX Tank Farm \\ Cone Penetrometer Demonstration Task \\ Training Plan}

\subsection{Introduction}

The Hanford Tanks Initiative (HTI) Cone Penetrometer (CP) Subsurface Characterization Demonstration task uses an existing piece of equipment (the Hanford CPP [CPP]), purchased in 1996, to push instrumented and soil sampling CP probes into the soils adjacent to tank AX-104. Correlation of data from the instrumented probes and the soil sample lab analysis data will demonstrate the use and capabilities of the probes to detect and measure specific constituents of the waste plume in the soil and target specific soil regions for sampling.

The CPP and CP probes used during the task are not currently planned for operational use or programs beyond the HTI task scope. The HTI CP task will not prepare the CPP and CP probes for turnover to Tank Farm Operations for routine operations use.

The overall objective of the HTI project subsurface characterization technology development and demonstration task is to demonstrate and evaluate CP technology that can be used to determine the location, extent, and contaminant concentration gradient of a single shell tank (SST) leakage-derived plume. This effort is planned to take place over a minimum two-year period (fiscal years 1997 and 1998). This task will focus on the backfill soils and vadose zone surrounding tank AX-104 in the 241-AX tank farm on the DOE Hanford Site. The soils will be interrogated (using CP-deployed sensors/samplers) for traceable contaminants of potential concern (COPC) including metals and gamma emitting radionuclides.

\subsection{Details of Training Deliverables .}

This section provides details of the training to be developed and delivered.

NOTES:

Course numbers given are temporary numbers created for the purpose of this report. ARA personnel will provide the Skill Verification Checklist Supervision. 


\subsubsection{General Overview of the CPP and CP Operations (TBD-001)}

This overview broadly covers the CPP and HTI CP operations. Specific topics include:

- Handout (AX Tank Farm CP Operations Control Plan)

- Purpose of the System

- System Description

- System Operations

- Safety Limits and Hazards

- Emergency Responses

- Characterization Project Operations (CPO) Work Instructions Overview

Prepared By: $\quad$ ARA, HTI, and CPO Personnel

Delivered By: $\quad$ ARA, HTI, and CPO Personnel

Tracking: $\quad$ Single course number (TBD-001) given at completion of course.

\subsubsection{CP Operations Control Plan Required Reading (TBD-002)}

A handout (AX Tank Farm CP Operations Control Plan) will be required reading for the Shift Operations Managers (SOMs). This handout covers the information required for SOMs to respond to any unusual occurrences.

Prepared By: $\quad$ ARA, HTI, and CPO Personnel

Delivered By: $\quad$ TWRS Training

Tracking: Double Shell Tank Farms SOMs required reading

\subsubsection{CP Nuclear Chemical Operators Skill Verification Checklist (TBD-003)}

This checklist guides Nuclear Chemical Operators (NCOs) through their activities during $\mathrm{CP}$ operations.

Prepared By: $\quad$ TWRS Training

Delivered By: TWRS Training

Tracking: $\quad$ Tracked with a continuing training number.

\subsubsection{Field Walkdown of the CPP (TBD-004)}

Walkdown of the CPP pointing out critical and significant components.

Prepared By:

Delivered By:

Tracking:
ARA Personnel

ARA Personnel

Course completion roster describing the specific topic addressed. These will be kept in TWRS Training Program Master Files. 


\subsubsection{Course Completion Rosters}

During the course of the HTI CP task, the Course Completion Rosters shall be kept with the CPP at the $\mathrm{CP}$ demonstration or storage location with a description of activities and list of names present when those activities occurred.

Prepared By:

Delivered By:

Tracking:
ARA, HTI, and CPO Personnel ARA, HTI, and CPO Personnel These Course Completion Rosters will be kept at the site of the CP Site until demonstration is complete, then turned over to the TWRS Training Records Program Master Files.

Completion of these activities will be documented as indicated. $\dot{A}$ tracking number will appear on the training records of those who completed the training. If additional CP sampling occurs, this activity is planned to eventually be incorporated into the CPO Certification Program 


\subsection{Job Responsibilities and Training Needs}

\subsection{CPO Nuclear Chemical Operators}

HTI and ARA personnel are primarily responsible for operating the CP. Characterization Project Operations (CPO) Nuclear Chemical Operators (NCOs) will support the HTI CP operations. $\mathrm{AX}-104 \mathrm{CP}$ operations will include $\mathrm{CPP}$ and associated equipment set up, moving the $\mathrm{CPP}$ and associated equipment, soil sampling, and equipment and push site clean-up activities. The above activities are the same type as, and within the scope of, routine work performed by NCOs in Tank Farms. However, additional activities include assisting the Washington State Certified Driller on the CPP and monitoring of pipe as it goes into, and is removed from the soil. As a result of the limited involvement of NCOs in this activity, training will only be required on the topics and activities listed below.

- General Overview, given by HTI personnel, of the CP to occur at the cold run pre-job Meeting (TBD-001)

- Skill Verification Checklist (TBD-003)

- Field Walkdown of the CPP (TBD-004)

\subsection{CPO Cask/Sample Transport Truck (CSTT) Nuclear Chemical Operators}

Characterization Project Operations (CPO) CSTT Nuclear Chemical Operators will accept the fieldgenerated $\mathrm{CP}$ [soil] samples for shipping to the labs. These staff must have familiarity with $\mathrm{CP}$ operations and general aspects of $\mathrm{CP}$ probe and $\mathrm{CPP}$ deployment. Their required training includes:

- General Overview, given by HTI personnel, of the CP operations and the Hanford CPP to occur at the cold run pre-job meeting (TBD-001)

- Field Walkdown of the CPP (TBD-004)

\subsection{CPO Supervisor}

The CPO Supervisor must be cognizant of the $\mathrm{CP}$ operations and general aspects of $\mathrm{CP}$ probe and $\mathrm{CPP}$ deployment. The following training is required:

- General Overview of the CPP and CP operations (TBD-001)

- Field Walkdown of the CPP (TBD-004) 


\subsection{PO and Double Shell Tanks (East Area) Shift Operations Managers}

Shift Managers will be required to have a level of understanding that gives them the knowledge necessary to respond to off-normal or emergency events. This training includes:

- General Overview of the CPP and CP Operations from a Training Handout (AX Tank Farm CP Operations Control Plan). (TBD-002)

- Field Walkdown of the CPP (TBD-004)

\subsection{CPO Health Physics Technicians}

Despite the fact that a new and unique piece of equipment is being used, no unique situations are planned or anticipated beyond those that radiological control technicians normally handle. Therefore, a general overview of the CP/CPP operation and equipment, and a field walkdown will provide adequate training. The following training will be provided to radiological control technicians:

- General Overview of the CPP and CP operations will be given by HTI personnel (TBD001)

- Field Walkdown of the CP (TBD-004)

\subsection{TWRS Crane and Rigging Personnel}

Operations involving Crane and Rigging will be within the bounds of normal activities, however, orientation with the $\mathrm{CP}$ will be required. The following training will be required:

- General Overview of the CPP and CP operations will be given by HTI personnel at the "cold" run pre-job Meeting (TBD-001)

- Field Walkdown of the CPP (TBD-004)

\subsection{CPO Technical Staff}

Cognizant Engineers will be required to sign off documents related to $\mathrm{CP}$ operations. For this reason, they must learn about the device and its operations. Cognizant Engineers will be expected to attend the following training, or be exempted from the training by [field] experience:

- General Overview of the CPP and CP operations will be given by HTI personnel (TBD001)

- Field Walkdown of the CPP (TBD-004) 


\subsection{Analytical Personnel (CP Deployment Team)}

Analytical Personnel will analyze the sample "in-situ". They must meet site and Tank Farm requirements in order to have access to these areas, and become familiar with $\mathrm{CP}$ operations by taking the following;

- General Overview of the CPP and CP operations will be given by HTI personnel at the "cold" run pre-job Meeting (TBD-001)

- Field Walkdown of the CPP (TBD-004)

- Field Activity Course Completion Rosters (TBD-005)

\subsection{CP HTI Process and Design Engineers}

These are the Subject Matter Experts who, due to participation in the design of the CP, do not require any additional training. Waste Management, HTI, and Characterization Staff will provide Process and Design Engineers. Technical expertise will be demonstrated prior to delivery of system through participation in design and development of the system and work instructions. These staff must meet site and Tank Farm requirements in order to have access to these areas, as stated in HNF-IP-0842, Vol. VII, Radiological Control, Section 2.4.

\subsection{CP Hanford Tank Initiative (HTI) Lead Technical Personnel}

ARA Staff will provide the technical lead for the CP push operations and the CPP. They will write the work instructions and provide supervision of the Skill Verification Checklist signoff. They must meet site and Tank Farm requirements in order to have access to these areas, as stated in HNF-IP0842, Vol. VII, Radiological Control, Section 2.4.

\subsection{TWRS Maintenance Personnel}

The CP includes items of equipment unique to the project. Vender (ARA) Staff will maintain these items. Members of the HTI Organization will maintain records of Vender Maintenance Personnel activities for potential future use in development of maintenance training.

No training will be given .

\subsection{Industrial Hygiene Technicians}

Industrial Hygiene Technicians will not be involved in the operating of the $\mathrm{CP}$. Therefore, no special training will be created or provided to Industrial Hygiene Technicians.

\subsection{Stationary Operations Engineers}

Stationary Operations Engineers (SOEs) are not required for any activities related to the operation of the CPP or CP probes, therefore, no training will be created or delivered to SOEs 


\subsection{Operations Engineers (OE)}

Operations Engineers who may act as Shift Managers for CPO or Double Shell Tank Operations during the operation of the $\mathrm{CP}$ must meet the requirements of the shift manager as stated above. 


\subsection{Training Plan}

\begin{tabular}{|c|c|c|}
\hline Training Deliverables & Audience & Schedule \\
\hline \multirow{7}{*}{$\begin{array}{l}\text { General Overview of the CPP and } \\
\text { CP operations (TBD-001) }\end{array}$} & CPO NCOs & Presented during a "cold" run Pre-job meeting \\
\hline & $\begin{array}{l}\text { CPO CSTT } \\
\text { NCOs }\end{array}$ & Presented during a "cold" run Pre-job meeting \\
\hline & CPO Supervisor & Presented during a "cold" run Pre-job meeting \\
\hline & HPTs & Presented during a "cold" run Pre-job meeting \\
\hline & C\&R Personnel & Presented during a "cold" run Pre-job meeting \\
\hline & CPO Tech Staff & Presented during a "cold" run Pre-job meeting \\
\hline & $\begin{array}{l}\text { Analytical } \\
\text { Personnel } \\
\end{array}$ & Presented during a "cold" run Pre-job meeting \\
\hline Training Bulletin (TBD-002) & Shift Managers & $\begin{array}{l}\text { Delivered in required reading for Double Shell Tanks } \\
\text { Shift Managers. }\end{array}$ \\
\hline $\begin{array}{l}\text { Skills Verification Checklist } \\
\text { (TBD-003) }\end{array}$ & NCO & Signed off by ARA Personnel during a "cold" run \\
\hline
\end{tabular}

\begin{tabular}{|c|c|c|}
\hline \multirow[t]{9}{*}{ Field Walkdown of CP (TBD-004) } & CPO NCOs & $\begin{array}{l}\text { All CPO NCOs attached to CP Operations to } \\
\text { complete }\end{array}$ \\
\hline & $\begin{array}{l}\text { CPO CSTT } \\
\text { NCOs }\end{array}$ & All CPO CSTT Operators to complete \\
\hline & CPO Supervisor & $\begin{array}{l}\text { The CPO Supervisor attached to CP Operations to } \\
\text { complete }\end{array}$ \\
\hline & $\begin{array}{l}\text { CPO Shift } \\
\text { Managers }\end{array}$ & All CPO Shift Managers to complete \\
\hline & $\begin{array}{l}\text { East Area Shift } \\
\text { Manager }\end{array}$ & All East area Shift Managers to complete \\
\hline & $\begin{array}{l}\text { Health Physics } \\
\text { Technicians }\end{array}$ & All HPTs attached to CP Operations to complete. \\
\hline & C\&R P'ersonnel & $\begin{array}{l}\text { All C\&R Personnel attached to CP Operations to } \\
\text { complete }\end{array}$ \\
\hline & $\begin{array}{l}\text { CPO Technical } \\
\text { Staff }\end{array}$ & $\begin{array}{l}\text { All CPO Technical Staff attached to CP Operations to } \\
\text { complete }\end{array}$ \\
\hline & $\begin{array}{l}\text { Analytical } \\
\text { Personnel }\end{array}$ & $\begin{array}{l}\text { All Analytical Personnel attached to CP Operations } \\
\text { to complete }\end{array}$ \\
\hline
\end{tabular}




\subsection{Continuing Training}

Because of the short and experimental nature of this operation, no scheduled continuing training will be created. If this project is accepted and turned over to operations, a separate training plan will address the new training requirements.

\subsection{Retraining}

There is no need for retraining because of the short duration of this operation.

\subsection{Dependencies}

For the TWRS Training organization to complete development and implementation according to this plan, the following support is required.

\subsubsection{Work Instruction Development}

TWRS Training organization will complete the Skill Verification Checklist one week after all work instructions related to the tasks in that checklist are approved by signature - provided that TWRS Training has access to the draft work instructions on demand, and operations will take no more than one day to review draft cards and guides.

\subsubsection{Operations Manager Support of Training Activities}

\subsubsection{Classroom Attendance}

TWRS Training has neither the resources nor time to support multiple classroom presentations above those designed in this plan. Managers must make all efforts to have their employees attend the courses given as scheduled.

\subsubsection{Skill Verification Checklist Completion}

The availability of knowledgeable Operations and Process Engineers will impact TWRS Training's schedule for making a Skill Verification Checklist available and in getting Operator Skill Verification Checklist Instructors prepared to instruct others. Operations Managers will need to give their operators the time necessary to complete their respective Skill Verification Checklist.

\subsection{Training Exemptions}

Certain personnel may be exempted from the training and given credit for such training based on their activities with development and trial of the CP. Exemptions will be requested and documented according to HNF-IP-0842, Volume III, Section 2.2, "Training Exceptions and Extensions". 


$$
H N F-3313, \operatorname{Rev} .0
$$

HTI AX Farm Cone Penetrometer Characterization Demonstration Task Training Plan Rev. 0

Approval Signatures
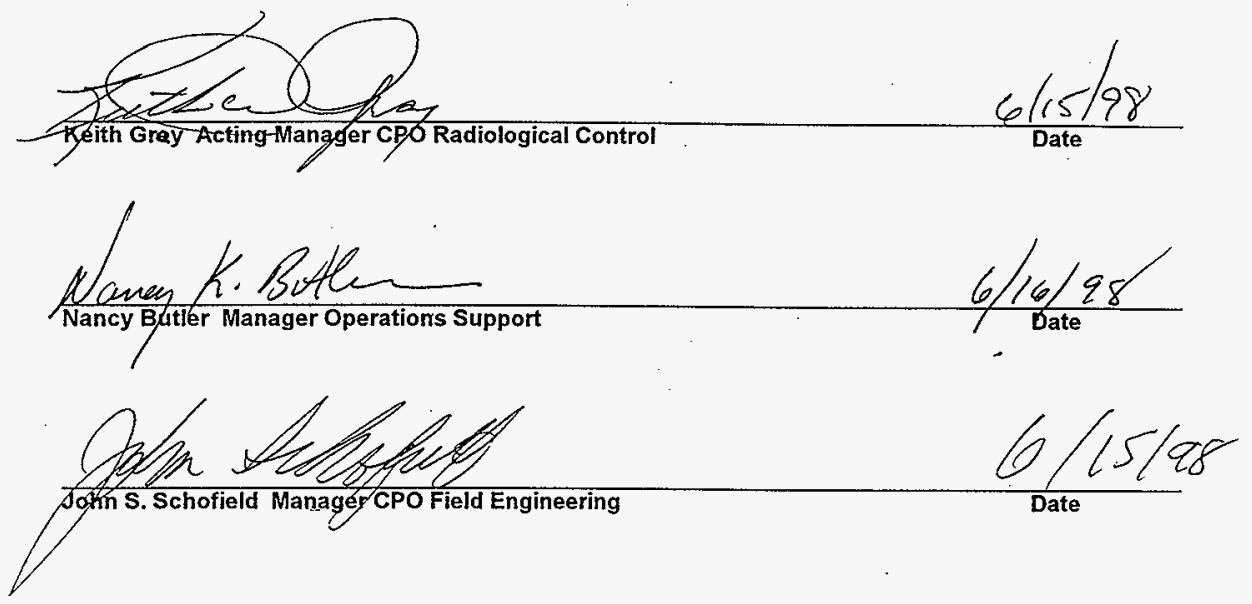

R.S. S. "Bob"Popielarczyk Manager Characterization Project Operations
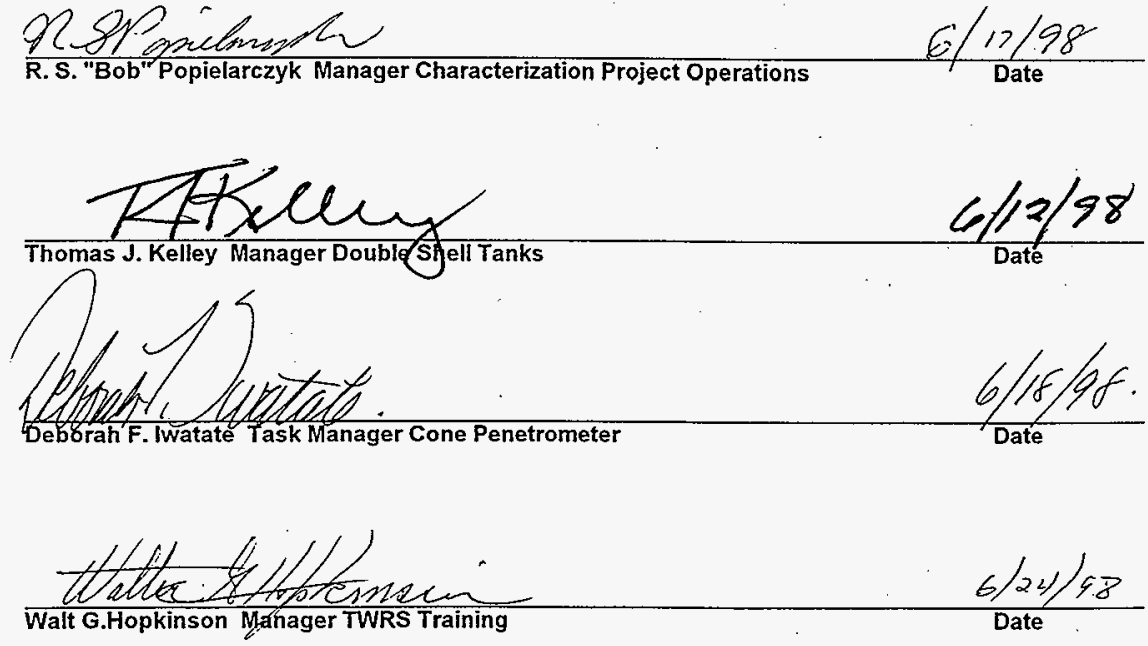

2

$p g .10$ of 10 


\section{DISTRIBUTION SHEET}

\begin{tabular}{|c|c|c|c|c|c|}
\hline \multirow{2}{*}{$\begin{array}{l}\text { To } \\
\text { Distribution }\end{array}$} & \multirow{2}{*}{\multicolumn{3}{|c|}{$\begin{array}{l}\text { From } \\
\text { Numatec Hanford Co., Project } \\
\text { Definition }\end{array}$}} & \multicolumn{2}{|l|}{ Page 1 of 1} \\
\hline & & & & \multicolumn{2}{|l|}{ Date $9 / 28 / 98$} \\
\hline \multicolumn{4}{|c|}{ Project Title/Work Order } & \multicolumn{2}{|c|}{ EDT No. 609268} \\
\hline \multicolumn{4}{|c|}{$\begin{array}{l}\text { Hanford Tanks Initiative AX Tank Farm CP Demonstration Training } \\
\text { Plan, HNF-3313, Rev. } 0\end{array}$} & \multicolumn{2}{|l|}{ ECN No. $\quad N / A$} \\
\hline & MSIN & $\begin{array}{l}\text { Text } \\
\text { With All } \\
\text { Attach. }\end{array}$ & Text Only & $\begin{array}{l}\text { Attach./ } \\
\text { Appendix } \\
\text { Only }\end{array}$ & $\begin{array}{l}\text { EDT/ECN } \\
\text { Only }\end{array}$ \\
\hline
\end{tabular}

$P$ Jennings

$\mathrm{R} 2-84 \cdot \mathrm{X}$

JJ Huston

R2-89 $X$

WJ Kennedy

S7-03 X

DA Bragg

S5-05 $X$

WS Callaway

\$3-90 X

DF Iwatate

R2-89 X

DB Hagmann

R2-89 X

R Root

$R 2-53$

X

AF Noonan

R2-89

X

GP Janicek

S7-12

X

KW Gray

S7-05

X

NK Butler

R3-01 $X$

JS Schofield

S7-12

X

RS Popielarczyk

\$7-01 $X$

TJ Kelley

S5-07 X

WG Hopkinson

R2-84

X

Central Files (1)

$B 1-07+17-09$

$X$

HTI Project Files

(1)

R1-29/ X 